$10-1988$

\title{
Social History, Psychohistory, and the Prehistory of Swiss Anabaptism
}

Peter Iver Kaufman

University of Richmond, pkaufman@richmond.edu

Follow this and additional works at: http://scholarship.richmond.edu/jepson-faculty-publications

Part of the Christian Denominations and Sects Commons, Christianity Commons, History of Christianity Commons, and the Religious Thought, Theology and Philosophy of Religion Commons

\section{Recommended Citation}

Kaufman, Peter Iver. "Social History, Psychohistory, and the Prehistory of Swiss Anabaptism." Journal of Religion 68, no. 4 (October 1988): 527-544.

This Article is brought to you for free and open access by the Jepson School of Leadership Studies at UR Scholarship Repository. It has been accepted for inclusion in Jepson School of Leadership Studies articles, book chapters and other publications by an authorized administrator of UR Scholarship Repository. For more information, please contact scholarshiprepository@richmond.edu. 


\title{
Social History, Psychohistory, and the Prehistory of Swiss Anabaptism
}

\author{
Peter Iver Kaufman / University of North \\ Carolina at Chapel Hill
}

In 1974, James Stayer and Martin Haas chanced to meet in the reading room of the Institut für schweizerische Reformationsgeschichte in Zurich. Both Stayer and Haas had been preparing papers for a volume scheduled to commemorate the 450th anniversary of the first Anabaptist baptisms. As they talked of their respective contributions, Stayer confided that he was trying to prove that the Swiss Anabaptists "were not at first sectarians," whereupon Haas promptly responded that he was working toward the same conclusion. From that time, what Stayer subsequently dubbed "the contextualist approach" to Anabaptist origins and Anabaptist history has been associated with the revisionist thesis that has dramatically altered ideas formulated and perpetuated by those exploring the theological approaches to radical Swiss religious dissent. ${ }^{1}$

The contextualists' thesis, to put it simply, is that Anabaptists' separatism and sectarian identity were reactions to several years of frustration. Swiss radicals did not begin by taking a principled stand against the political compromises made by several leading reformers. The articulation of principles followed years of intermittent agitation against tithes and clerical indolence. Contextualists are reluctant to track the origins of sectarian religious dissent to reformation biblicism or to the moral earnestness of several outspoken dissidents. They sense that they have found the origins of reformation radicalism in the social and economic dissent that spread through south Germany and Switzerland by 1525. Separatism surfaced only after militant action failed. Two years after "the peasants' revolution" was suppressed and five years after the initial expressions of dissatisfaction in and around Zurich, Anabaptists in Schleitheim made something

1 The conversation is reported in James Stayer, "The Separatist Church of the Majority," Mennonite Quarterly Review 57 (1983): 152, 155; but also consult his contribution to Reformation Europe: A Guide to Research, ed. Steven Ozment (St. Louis, 1982), pp. 135-53.

( 1988 by The University of Chicago. All rights reserved. 0022-4 189/88/6804-0003\$01.00 
of a manifesto out of "the sectarian elements left behind after the radical social movement ... ebbed away." 2

Contextualists are conscientious social historians; if they have their way, social movements and anticlerical currents will soon replace individual character in explanations of the "how" and "why" of religious reformations from East Anglia to Zurich. It would not be an altogether disastrous development. Character too long has obscured social context in historical narrative, but before one single-factor theory replaces another, we want to register some reservations about such great changes in historical scholarship.

It must be conceded that historians were once too eager to reduce the story of religious reform to the character and the theology of one or another influential reformer. For generations, closely argued propositions about the immense authority of sixteenth-century theologians and preachers kept social historians outside the citadel, much as those great doors of fitted planking kept Troy secure. But the city has been under siege for years. If we believe one enthusiastic assailant, historians hostile to notions of socioeconomic causation have already been put to flight. There is no denying, however, that older citizens of the city have considerable staying power, although their disciples are learning rapidly to pick their ways through pamphlets, propaganda, council records, writs, and other excrementa of institutional affairs. The results have been bracing, particularly as scholars more expert in the contextual approach continue to restore the social and political contexts of late medieval religious dissent. Their restorations, in fact, enable historical theologians and biographers to broaden their appreciations for the grand ideas and the careers that still fascinate and preoccupy them. ${ }^{3}$ But applied exuberantly, the contextual approach often cuts a few too many ideas and careers from history's script. The impresarios of territorial reformations sometimes sink from sight beneath those currents of popular sentiment that social historians have been busy rediscovering.

The profit and the peril of the contextualist approach to the history of

2 See Hans-Jürgen Goertz, "Das Täufertum-ein Weg in die Moderne?" in Zwingli und Europa, ed. Peter Blickle, Andreas Lindt, and Alfred Schindler (Zurich, 1985), pp. 173-75; and James M. Stayer, Werner O. Packull, and Klaus Depperman, "From Monogenesis to Polygenesis: The Historical Discussion of Anabaptist Origins," Mennonite Quarterly Review 49 (1975): 100.

3 See R. W. Scribner ("the enthusiastic assailant," in this instance), The German Reformation (Atlantic Highlands, N.J., 1986), p. 40, but also consult Scribner's papers, "Is There a Social History of the Reformation?" Social History 2 (1977): 483-505, and "Religion, Society, and Culture: Reorienting the Reformation," History Workshop 14 (1982): 2-22, and his probing work on evangelical literature, For the Sake of the Simple Folk: Popular Propaganda for the German Reformation (Cambridge, 1981). To this list of impressive contextualist studies, add Thomas A. Brady, Turning Swiss: Cities and Empire, 1450-1550 (Cambridge, 1985); and the contributions to Stadtbürgertum und Adel in der Reformation, ed. W. J. Mommsen, P. Alter, and R. W. Scribner (Stuttgart, 1979). 
religious reform come into sharper focus if we return to that library in Zurich and if we review the thesis advanced by Stayer and Haas. If we then return to sixteenth-century Zurich, introduce the career of Conrad Grebel, and reconsider the development of Swiss separatism, we should be able to suggest some ways in which profits can be drawn and perils avoided. ${ }^{4}$

\section{THE NORMATIVE VISION AND CONTEXTUALIST REVISIONS}

The normative vision of Anabaptist history may be reduced to two related propositions. The first alleges that Conrad Grebel and other radicals practiced what Huldrych Zwingli and Martin Luther preached and therefore that the radicals were the sixteenth century's genuine and more thorough reformers. Others contrasted the standards of the Christian scriptures with the ways of the world, yet they appeared to compromise their principles in order to purchase government cooperation. The radicals, however, stood by their contrasts and recreated scriptural churches distinct from the corrupt and corrupting political order. The second proposition alleges that the radicals in Zurich were prototypical. Different versions of their protest evolved as dissent spread to other cities and through the countryside. Advocates of the normative vision could hardly overlook the variations, yet they branded most of them aberrations. Radicals who had tried to build a broad consensus and particularly those radicals who had resorted to force were said not to have been "real" Anabaptists. Normative Anabaptism often might be characterized by insolence and disobedience with respect to (or, more accurately, with disrespect for) the public authorities, but authentic Anabaptists were resigned to suffer for their antisocial behavior. In 1524, Conrad Grebel reported that leading reformers were bent on becoming the new popes of a partially reformed Christendom, so it was clear to him that "Christ must suffer still more in his [more faithful] members." 5

\footnotetext{
4 Hans-Jürgen Goertz edited the volume in which Stayer and Haas introduced their contextualist approach to Anabaptist separatism, Umstrittenes Täufertum, 1525-1975 (Göttingen, 1975). The substance of Stayer's paper, "Die Anfänge des schweizerischen Täufertums im reformierten Kongregationalismus," reappears in several of his essays in English, particularly in "The Swiss Brethren: An Exercise in Historical Definition," Church History 47 (1978): 182-86, and "The Revolutionary Beginnings of Swiss Anabaptism," in The Origins and Characteristics of Anabaptism/Les debuts et les characteristiques de l'Anbaptisme, ed. Marc Lienhard (The Hague, 1977). Parts of Haas's contribution to Umstrittenes were translated (but without annotations) in The Anabaptists and Thomas Müntzer, ed. James M. Stayer and Werner O. Packull (Toronto, 1980), pp. 72-84 (citations that follow, however, refer to the original, “Der Weg der Täufer in die Absonderung").

5 See Grebel's letter to Thomas Müntzer, in Quellen zur Geschichte der Täufer in der Schweiz, vol.
} 
The second of the two propositions came unstitched a dozen years before the contextualists coordinated their assault on the apparent swissification of Anabaptism. Hans Hillerbrand, for instance, claimed that the normative vision's assumptions about Swiss origins would not stand careful inspection. He suggested that radicals in Saxony induced Zurich dissidents to complain about the weak tea served by $\mathrm{Z}$ wingli. ${ }^{6}$ Other historical theologians censured their colleagues who remained attached to the normative vision's first proposition, that is, to the statement that Anabaptism carried forward reformation innovations when the first innovators showed themselves to be compromisers or conservatives or cowards. Critics found that this contention sounded more like sectarian apology than reformation history. Even Anabaptism's more ardent admirers, without denying that the radicals' commitments to scriptural standards and to discipleship completed the reformation's work, qualified the normative vision of Anabaptist origins by tracing the pedigree of the radicals' ideas to the thirteenth century. Some dared to argue that Anabaptism was not so much an advance of the Protestant causes as a throwback to monastic and mendicant efforts to reawaken interest in earliest Christian piety. ${ }^{7}$ Notwithstanding the damage, the normative vision still fascinated scholars at the time that Stayer and Haas discovered each other. Resourceful visionaries had stocked their case so well that social historians had to clear ideas about various reformers' courage or cowardice before they could make a place for their own arguments about the separatism of "the more radical reformation."

The contextualist revision usually starts by identifying different Anabaptist positions on exegesis and on infant baptism. Hans-Jürgen Goertz, for example, collected variations as if he were collecting tinder for the great fire that would consume all troublesome misconceptions. Goertz claims that the diversity proves that no single set of ideas was normative. And since "the more radical reformation" was not coherent theologically, it should not be considered theologically more complete than the reformations that the radicals criticized. The radicals, according to Goertz, did

1, ed. Leonhard Von Muralt and Walter Schmid (Zurich, 1952), pp. 20-21 (hereafter QGTS). Also consult Clarence Bauman, Gewaltlosigkeit im Täufertum (Leiden, 1968), notably pp. 289-97; and John Howard Yoder, Täufertum und Reformation in der Schweiz (Karlsruhe, 1962).

6 Hans J. Hillerbrand, "The Origin of Sixteenth-Century Anabaptism: Another Look," Archiv für Reformationsgeschichte 53 (1962): 152-80.

7 Arnold Snyder, "The Schleitheim Articles in Light of the Revolution of the Common Man: Continuation or Departure," Sixteenth Century Journal 16 (1985): 426-28; but also note Snyder's "The Monastic Origins of Swiss Anabaptist Sectarianism," Mennonite Quarterly Review 52 (1983): 5-26; and Kenneth Ronald Davis, Anabaptism and Asceticism: A Study in Intellectual Origins (Scottdale, Pa., 1974), particularly pp. 31-32, 65-128, 232-43 for significant refinements with respect to the position advanced in the nineteenth century by Albrecht Ritschl.

${ }^{8}$ See Werner O. Packull, "Some Reflections on the State of Anabaptist History: The Demise of a Normative Vision," Sciences religieuses'/ Studies in Religion 8 (1979): 319-23. 
not agonize over the problems that prompted Luther or Bucer or Zwingli to question the Catholic order of salvation. The Swiss radicals had not even bothered to express themselves clearly on the central issue of justification. Goertz admits that Anabaptism, wherever it erupted, sported features that tempt scholars to speak of the movements as if they were one phenomenon, but he argues that similarities were not symptomatic of a common "theological root." To Goertz and other contextualists, similarities indicate instead that radical religious dissent was a function of the radicals' common social situation. Economic exploitation and social restrictions impelled radicals in Strasbourg, Swabia, and Switzerland to voice their anticlerical sentiments, their ambitions for greater lay authority in the churches, and their suggestions for the reform of political culture. Protests led to action, and action led to reaction. An increasingly oppressive social and political situation generated a new consensus on the need for a more radical reformation, a consensus that was carried along on those "anticlerical currents" that leading reformers were unable to contain. ${ }^{9}$

To a point, the radicals were encouraged. In Zurich, Zwingli endorsed some of the sentiments that he would later deplore. The Zurich government also seemed to support petitions against the city's largest churches and religious foundations, which possessed extensive rights to choose incumbents for, and to gather revenues from, the parishes in the countryside. But radicals were not content to have a tithe revoked here and a tax collector intimidated there. They made sweeping demands for parish autonomy, demands that distressed Zwingli, who asserted thereafter that tithes were wholly legitimate and that the radicals' defiance of their magistrates would be unpardonable. ${ }^{10}$

Social historians have stalked Zwingli and the Zurich radicals through the archives. They know that by December 1523, the coalition, such as it was, had all but cracked apart, but they insist that the radicals' spokesmen were not yet inclined to adopt a separatist strategy. On the contrary, contextualists suggest that some radicals were contemplating a coup that would rid the canton of its more timid and conservative reformers. This is what Stayer and Haas mean when they announce that the Swiss Anabaptists "were not at first sectarian."

9 Hans-Jürgen Goertz, Die Täufer: Geschichte und Deutung (Munich, 1980), pp. 19-20, 53-54, 96-97, and "Das Täufertum" (n. 2 above), pp. 167-72. Also note Martin Haas, "Täufertum und Volkskirche-Faktoren der Trennung," Zwingliana 13 (1970): 272-76, and "Der Weg der Täufer in die Absonderung" (n. 4 above), pp. 57-60.

10 See e.g., Huldrych Zwingli's "Wer Ursache gebe zu Aufruhr," in Huldreich Zwinglis sämtliche Werke, ed. Emil Egli et al., 14 vols. (Berlin, 1905-59), 3:383, 397 (hereafter ZW). Also consult J. F. Gerhard Goeters, "Die Vorgeschichte des Täufertums in Zürich," in Studien zur 


\section{The Journal of Religion}

Stayer, Haas, and Goertz place incredible weight on the suppression of the peasant insurrections of 1525 . All radicals, they allege, were jostled into a corner and given a new "socio-religious identity" from which Anabaptist separatism developed once the victims made a virtue of their victimization. Have contextualists forgotten that as early as $1524 \mathrm{Grebel}$ had urged radicals to secede from the more popular reformations and had commended suffering to the secessionists? The contextualist thesis cruises too quickly past such statements and then docks at the rather dubious conclusion that separatism and suffering, for the most part, were choices made for the radicals rather than choices made by them.

The greater problem with the contextualist revision is that individuals along with individual choices tend to get lost in the crowds, masses, and currents that social historians have either discovered or invented. Where Grebel is concerned, this loss would truly be lamentable because the early part of his career is so well represented by his correspondence, and another look there might restore what the contextualist approach has planed away, namely, the revealing complications of this complicated character."

\section{CONRAD GREBEL AND THE PREHISTORY OF SWISS ANABAPTISM}

Until Harold $S$. Bender draped careful research and cautious conjecture around his biography of Conrad Grebel in 1950, persons interested in the reformations' most radical Protestants were fed meager rations. Much of what they knew about the radicals came from other reformers' curses and condemnations. But Bender built a solid case for the normative vision with his life-and-times approach to Grebel and to the origins of Anabaptism. Although silences and rationalizations with respect to Grebel's severe mood swings and self-pity should have aroused suspicion, the reputation of Bender's biography was thick-ribbed.

Bender stressed the importance of ideas: purportedly the great change in Grebel's life resulted when he traded the "neutral humanist" attitudes toward religion, which he acquired from his instructors in Vienna and Paris, for Huldrych Zwingli's scriptural program for the reform of the Swiss churches. According to Bender, Grebel was so taken with Zwingli's ideas that he was ready to take them farther than $Z$ wingli would allow. From Zwingli's perspective, Grebel and his associates were reckless and impatient. They wanted too much too soon, and thus they endangered the

Geschichte und Theologie der Reformation, ed. Luise Abramowski and J. F. Gerhard Goeters (Neukirchen, 1969), particularly pp. 267-72.

11 For typical contextualist assessments of Grebel, see Haas, "Die Weg der Täufer in die Absonderung," pp. 76-77; and Goertz, Die Täufer, pp. 14-19. 
reformation's ultimate success by alienating moderates and conservatives on the city's councils. Bender underscored the radicals' courage and their steadfast allegiance to the first principles of the reformation that dictated, as far as Grebel and Bender were concerned, the simplification of worship and the elimination of unscriptural practices.

Bender's Grebel was neatly tailored for the traditional, normative, theological vision of Anabaptist origins. The Zurich radicals were the authentic Anabaptists. When they were convinced that Zwingli shamelessly courted the city's political officials, they evangelized independently and defied the government. They surely expected reprisals, but they were ready to suffer for their cause. Long before measures were passed against them, they accepted that their fate was to exhibit the Scripture's truths and power with their fugitives' lives and martyrs' deaths. ${ }^{12}$

At both ends of his story, Bender has drawn some questionable conclusions. Grebel's grudge against Zwingli is all but reduced to an exegetical and theological disagreement about the place of politics in Zurich's religious reformations. We shall soon see that such a simplification purges too much from the record. It will be best to start, however, with another of Bender's simplifications, his notion that Grebel passed from a "carefree" life of classical studies into the reformation when he met $Z$ wingli. The tale is encumbered with ideas about humanists' alleged indifference toward religion, ideas that were obsolete when Bender adapted them to Grebel's story. The suggestion that Grebel was carefree is still more bewildering, inasmuch as Grebel's first letters overflow with doubts and selfdeprecation. He brooded constantly over the sincerity and the survival of his friendships as if they were fragile barges in rough seas.

In part, Grebel's expressions of anxiety are attributable to the basic cast of humanist correspondence. Northern European humanists restlessly guarded their friendship networks, through which they hoped to promote the reform of education and the study of classical languages and literature. Erasmus of Rotterdam was particularly apprehensive. He frequently reminded friends and correspondents that literature was under attack, and he warned that humanists themselves might accomplish what their barbarous enemies and the enemies of learning were thus far powerless to achieve. Correspondents, he grieved, often were distracted. Letters would go unanswered. Worse still, familiar symptoms of humanists' disputes-obduracy, resentment, and envy-dismantled humanism's friendship networks. Grebel was nearly as vigilant and as nervous. ${ }^{13}$

12 See Harold S. Bender's Conrad Grebel, 1498-1526 (Goshen, Ind., 1950), pp. 66-77, 91, 96, $123-35,179,195,211-12$.

19 See, e.g., Erasmus's remarks in Opus epistolarum Des. Erasmi Roterodami, 12 vols., ed. P. S. 


\section{The Journal of Religion}

Flattery held things together, and humanists routinely served up flattery with dollops of self-abasement. Grebel feigned amazement that learned and distinguished friends would have anything to do with him, with their self-diminished admirer. He confided to Zwingli in the summer of 1518 that he had sent his slapdash and contemptible little letter only in order to attest that he knew just enough to esteem scholarship and erudition in others. He had not yet met Zwingli, who was preaching then in Einsiedeln, but he had heard of Zwingli's love for learning and affection for Erasmus. Grebel wanted Zwingli to visit Zurich, to join with his other humanist friends. Should he be unable to arrange the trip, at the very least, Grebel insisted, Zwingli must promise to shower his suitor with letters. For his part, Grebel promised to make those letters from Einsiedeln so welcome (crebris osculis dissuaviabor) that they would want to follow him everywhere. ${ }^{14}$

Grebel's overtures and invitations of this nature were the cables for his own friendship network. He also forwarded manuscripts composed by one friend to others so that praise and flattery might bind authors together (and to Grebel). He sent one of Vadian's works to Grebel. Later in 1518, he distributed Vadian's texts among his own friends in Paris. Rather than paraphrase their reviews, he included several tributes along with original material popular in Paris when he wrote to his Swiss friends. Grebel was busy constructing his literary "circle" or community, some tenants of which soon were treated to appeals of a very personal character.

Grebel's letter to Vadian in October 1518, was filled with flattery. A copy of Erasmus's Julius exclusus was enclosed. As a matter of course, Grebel also packed several expressions of his own insignificance: because he was woefully inept, Vadian must write him longer letters and thereby teach him to become eloquent. ${ }^{15}$ Grebel was more obsequious than Erasmus had been at his age, perhaps because Erasmus had petitioned his peers while Grebel addressed his requests to older and better-known scholars. He tended to make several of them surrogate fathers, particularly when friction developed in his family and when his craving for friendship perceptibly blended with his desires for fatherly affection. "You counsel me like a father," he told Vadian. "I am not certain that my

Allen, H. M. Allen, and H. W. Garrod (Oxford, 1906-58), 1:162; but also note Peter Iver Kaufman, "The Disputed Date of Erasmus's Liber Apologeticus," Medievalia et Humanistica, n.s., 10 (1981): 148-51.

14 ZW, 7:91-92.

15 Vadianische Briefsammlung, 7 vols., ed. Emil Arbenz (St. Gallen, 1891-1913) 2:204 (hereafter $V B$ ): "ad me prolixa epistola scribas quid deploratissimi ingenii homuncioni, ut prompte narrationis copiam, ut eloquentiam aliunde utcunque converram. ..." The letter is translated in The Sources of Swiss Anabaptism: The Grebel Letters and Related Documents, ed. Leland Harder (Scottdale, Pa., 1985), pp. 70-74 (hereafter SSA). 
own father could play the part of counsellor quite as well."16

One need not read far into Grebel's correspondence to find that family problems preoccupied him. His father, Jacob, increasingly mistrusted him after having received distressing reports from Vienna and then from Paris of his son's disreputable conduct. Jacob Grebel readily believed that Conrad and his undisciplined student companions courted danger every time that they closed their books. During a brawl in Paris, the younger Grebel and his comrades killed two thieves who had accosted them, and this episode especially alarmed his father who refused to send his son money that would have enabled him to settle his debts and to journey home. When he heard that his sister was soon to marry his trusted friend and confidant Vadian, Conrad became desperately homesick. His father was persuaded that he had misspent monies that previously had been advanced, and he would provide no more. Conrad Grebel complained bitterly in his letters to friends that his father had placed the worst possible interpretation on the evidence of his son's misbehavior. He accused Jacob of incomparable cruelty. He pronounced himself the most wretched man in Paris. Although he intended to congratulate Vadian and to declare his enthusiasm for the match, Grebel ended his appeals for Vadian's help with talk of funerals and epitaphs-unambiguously his own. ${ }^{17}$

Jacob Grebel finally relented, and his son returned to Zurich, too late for Vadian's wedding yet perhaps with some thoughts about ending his bachelorhood, for he was in love soon after his homecoming. The war between father and son, however, flared again because Jacob disapproved of the bride-to-be. Conrad thereupon made some rather odd plans for his elopement. He sent his intended ahead to Basel and then collected funds for his own escape. His departure was delayed, first by his father's illness and then by troubling interviews with Jacob Grebel during and after his convalescence. Conrad consoled himself with letters. He told friends how unreasonable and stubborn his father was. He virtually sobbed to Vadian that his own health was imperiled, his nights were sleepless, and his days clouded with debilitating despair. Although he was now on the threshold of marriage, Grebel still was prophesying his own death. ${ }^{18}$ Literature now was no distraction. He confessed that he merely moped about pretending to study. Only when his father again capitulated and when he left Zurich

$16 \mathrm{VB}, 2: 206$ : "Adeo non male et paterne consulis, ut nesciam, an pater tam bene consulem in rebus meis egerit." For Erasmus's early friendships, see Yvonne Charlier, Erasme et l'amitié d'après sa correspondance (Paris, 1977), pp. 341-42.

$17 V B, 2: 263$; and $S S A$, pp. 97-100. Also consult $V B, 2: 249$ : "Utcunque me enecent more solito ira patris et fortunae odium." Grebel's subsequent letter to Myconius shows that he soon suspected that Vadian had become unsympathetic. SSA, pp. 102-3; and Mennonite Quarterly Review 2 (1928): 238: "Et quoniam non cessas unquam ad me tam amice scribere, tam opportune, et tunc nempe cum meae animae mea praesidia parens et Vadianus me negligunt."

$18 V B, 2: 228$. 
for Basel did it seem that Conrad Grebel at last had made a decisive bid for autonomy. ${ }^{19}$

Grebel's getaway, however, brought no peace to the family. His parents implored him to return, and they recruited Vadian to help lure him back. One can snoop around for reasons-perhaps Jacob Grebel feared the effects of his son's license on his own promising political career-but there is nothing definite, save the arguments offered by Vadian and accepted by his correspondent, who claimed that he had returned for reasons of health. Only when his father left Zurich on business did Grebel marry the woman who so displeased his family, yet poverty then forced the young couple into the family home. Grebel's letters alluded to the enduring tension. His longing for friendship understandably was now an undisguised search for stays and steadying influences.

Late in 1521, Grebel rediscovered Zwingli, who had left Einsiedeln several years before and was then one of Zurich's three people's priests. Zwingli had just launched his campaign for church reform and he was looking for aides and allies. By August 1522, he could write to Oswald Myconius, who had moved to Lucerne, that Grebel was one of several young men who had enlisted in his "army." ${ }^{20}$ In fact, Zwingli's soldiers had gotten their first taste of battle the previous month. Preachers encouraged by the city's conservatives dared to defend practices that Zwingli had attacked in his own sermons. The reformation's opponents tried to vindicate such time-honored customs as the collection of relics and the veneration of saints, but Zwingli's friends disrupted their sermons and demanded scriptural proofs. Conrad Grebel was among the protestors, and he was summoned by the government to answer for the disturbances.

Bernhard Wyss, a contemporary chronicler, took up the story with Grebel's hearing, for it proved to be a rather dramatic confrontation. Just as the council instructed Grebel and other agitators to desist from further mischief, the chamber was filled with commotion (ein grossen schnall). Councilman Schliniger speculated that the devil was loose in the room, which prompted Grebel to add that the devil was not only in the room but he was seated among the very judges who had silenced the enemies of unscriptural and reactionary preaching. Grebel went on to scold the government for tolerating and protecting the idolatries and superstitions that cluttered Catholic worship. He solemnly warned that God would repay such irreverence unless changes were made immediately. ${ }^{21}$

Zwingli did not long stick to the sidelines. Several weeks after Grebel,

$19 V B, 2: 337 ; S S A$, p. 136.

$20 \mathrm{ZW}, 7: 568$.

21 Die Chronik des Bernhard Wyss, 1519-1530, ed. Georg Finsler (Basel, 1901), p. 15; and Emil Egli, ed., Actensammlung zur Geschichte Zürcher Reformation, 2 vols. (Zurich, 1879) 1:94. 
despite his outburst, was dismissed with only a reprimand, Zwingli ignored the government's restrictions and interrupted a sermon delivered by Franz Lambert of Avignon, who had come to Zurich to assist the Dominicans against the reformation. ${ }^{22}$ Possibly, in this instance, the general borrowed tactics from his troops, but it is much more likely that Zwingli, Grebel, and others cited for the summer disturbances conspired from the start. In any event, Grebel found $Z$ wingli an admirable confederate. Zwingli's intervention coaxed the government to call a special session of the council to hear Lambert and Zwingli debate their disagreement, and there are no grounds for doubting the account left by Wyss: Lambert conceded defeat, theatrically renounced his errors, and pledged to surrender his rosary. ${ }^{23}$ To this point, Conrad Grebel could not have been better satisfied with the progress of his reformation. He wrote cheerfully to Vadian about the successes in Zurich and about the "incorruptible" Zwingli who had engineered them. ${ }^{24}$

$\mathrm{Zwingli}$ continued to court government support. If he could rely on the magistrates' cooperation, he could more confidently parry the bishop's objections to the changes that he was determined to make. Grebel's part in the planning at this stage is somewhat unclear. We know that he considered the bishop a contemptible crook; Zwingli's enemies had become his enemies. ${ }^{25}$ But not all Zwingli's allies were Grebel's allies. The Zurich councils harbored some reservations about the effects of rapid reforms, reservations that $\mathrm{Z}$ wingli increasingly was prepared to accommodate but that Grebel was not.

By the end of 1523, Zwingli agreed to postpone some of the innovations and changes in worship for which he and his accomplices had lobbied. Grebel was obtrusively critical of the concessions. Perhaps, as Zwingli later guessed, Grebel desired to seize the initiative and to stage a revolution within the Swiss reformation. After all, he sympathized with outspoken dissidents who had defied authorities in several nearby villages, the same dissidents, according to the contextualists, who led "mass movements" for sweeping ecclesiastical and political reform. Nonetheless, a

22 See Heinold Fast, "Reformation durch Provokation: Predigtstörungen in den ersten Jahren der Reformation in der Schweiz," in Umstrittenes Täufertum (n. 4 above), particularly pp. $89-91$.

23 Die Chronik des Bernhard Wyss, pp. 16-17: "Do brach meister Ulrich das alt und nüw testament ... und bracht den münch darzu, dass er beid hend zusamenhub, danket Gott und sprach, er wolt in allen sinen noten allein Gott anruffen und alle kronbatt und rosenkrenz verlassen und Gott anhangen." Also see Gottfried W. Locher, Die zwinglische Reformation im Rahmen der europäischen Kirchengeschichte (Göttingen, 1979), pp. 99-102.

$24 V B, 7: 17 ; S S A$, p. 193.

$25 V B, 3: 235 ; S S A$, p. 191. Bishop Hugo of Constance regularly complained of Zurich's usurpation of episcopal prerogatives. See Hans Morf, "Obrigkeit und Kirche in Zürich bis zu Beginn der Reformation," Zwingliana 13 (1970): 164-205. 
closer look at the village radicals and at Grebel, who repudiated precipitous and militant action, reveals significant differences. ${ }^{26}$ I suggest, therefore, that we canvas the reasons for Grebel's grudge against Zwingli without leaving the city of Zurich, and we may do so by placing Zwingli's efforts to appease the government in the context of Grebel's family history.

For Zwingli, the days for disruptive tactics had passed by the time that Leo Jud, who had succeeded him in Einsiedeln, joined him in Zurich in 1523. Just when Grebel thought he had found a mentor and intimate friend, Jud became Zwingli's right hand and presided over the campaign to have images and statues removed from the city's churches. ${ }^{27}$ Zwingli and Jud prevailed upon the government to appoint a commission that would sort through the reformers' objections to Catholic worship. Eleven councilmen met with Zwingli, Jud, and Heinrich Engelhart, the third of Zurich's three people's priests, to arrive at some settlement that conservative members of the councils could endorse. As deliberations proceeded, Zwingli scrapped his radical proposals. He and Jud accepted a compromise; but to see that compromise with Grebel's eyes, we must know that one of the councilmen on the commission, which apparently neutered the reformers' grand designs to outlaw the mass, was none other than Grebel's father. ${ }^{28}$

Conrad Grebel promptly declared that he was finished with Zwingli, yet he was not true to his word. Discussions between the two dragged on during the next year (1524). When the councils ignored the commission's recommendation that each congregation be allowed to suspend the mass if parish consensus to that effect could be reached, Grebel and his friends believed that they might pry Zwingli from his faith in the government's goodwill. It was soon obvious, however, that Zwingli and Jud were prepared to weather setbacks and to preserve their partnership with the city's officials. In Grebel's view, Zwingli had betrayed the original goals of the reformation, or, to put it another way, Zwingli's reformation had reached an impasse and had turned back. Grebel's more radical reformation, pressing forward, became the nucleus of Swiss Anabaptism. ${ }^{29}$

26 See $Z W, 6: 33$; but cf. Heinold Fast, "Die Wahrheit wird euch freimachen," Mennonitische Geschichtsblätter 32 (1975): 13-14, 24.

27 See Goeters (n. 10 above), pp. 271-72; and Karl-Heinz Wyss, Leo Jud: Seine Entwicklung zum Reformator, 1519-1523 (Frankfurt, 1976), pp. 114-22, 131-32.

28 Egli, ed. (n. 21 above), $1: 167$ and $1: 183$.

29 See Yoder (n. 5 above), pp. 162-65. Yoder blames Zwingli for the break and maintains that Zwingli suddenly changed his mind about the character of the church's relationship to government; Robert Walton acquits Zwingli and implies that Grebel misperceived his mentor's true purposes. See Robert Walton, Zwingli's Theocracy (Toronto, 1967), pp. 190-208, and "Was There a Turning Point of the Zwinglian Reformation?” Mennonite Quarterly Review 42 (1968): 45-56. 


\section{PATHOGRAPHY AND PSYCHOHISTORY}

Pondering the origins of Anabaptism, social historians tend to measure disaffection and resentment almost exclusively in socioeconomic terms. We invoked Conrad Grebel's early career to introduce the prospects for a more complete understanding of radical dissent, and it requires no coaching from behavioral scientists to suggest that Grebel's filial defiance somehow was recycled in his reactions against $Z$ wingli and the Zurich councils. Zwingli's compromises alienated most of the radicals who had joined his troop before the summer disturbances of 1522. Arguably, however, the compromises had a greater effect on Grebel, whose father conspired with Zwingli to accommodate politically cautious councillors. Conceivably, the deliberations during the winter of 1523 reminded Grebel of family friction and of his previous frustrations; yet to what limit can we carry these arguable and conceivable propositions? At what point, if at any, do the arguable and conceivable, in this case, become plausible? If answers are to be found, pathography may find them, although pathography is simply the narrative illustration of patterns of behavior that document the development of character.

One need not endorse Peter Loewenberg's contention that "all human actions realize implicit trends within past situations" to allow that many important and ostensibly sudden or spontaneous decisions were rooted in prior experiences, actions, conflicts, and resolutions. Pathographers, like most biographers, look for those "implicit trends" that connect the prior with the present. Narrative illustration, if successful, makes the implicit explicit and makes the explicit appear self-evident. Critics from one camp, in which the psychoanalytically sophisticated reside, find it difficult to forgive pathography's reluctance to appeal to one or another of the rival theories of psychoanalytic development. To say that pathography is defined by the absence of interpretation, however, is unpardonable. Narrative itself is interpretation; usually if one scratches a pathographical narrative, one also finds some of the best and ordinarily some of the least controversial ideas of those psychoanalysts and psychohistorians who have enabled pathographers to identify patterns of conduct and to evaluate their subjects' personal crises. ${ }^{30}$

What keeps pathography from becoming psychohistory is a certain skepticism about psychoanalysis and psychoanalytic theory. Psychoanalysts often tunnel so deeply into the recesses of personality and return with

30 Compare Thomas A. Kohut, "Psychohistory as History," American Historical Review 91 (1986): 340-41: "At best, pathography is a form of pointless historical gossip as the intimate details of a public figure's personal life are exposed for their own sake." For Peter Loewenberg's remarks on "implicit trends," see his Decoding the Past: A Psychohistorical Approach (New York, 1983), p. 11 . 


\section{The Journal of Religion}

such strange stories and souvenirs (complexes, instincts, transferences, and defenses) that pathography cannot take advantage of such subterranean exploits without producing skewed rather than straightforward studies of human character. Undeniably, however, psychoanalysis has made pathography and all history slyly sensitive to the immense influence of the family environment.

The discovery of family tensions occasionally induces historians to recount adult behavior in ways that enviably illumine their subjects' careers. Yet historians' obsessions with family tensions can lead to reductionism and can handicap historical understanding. According to Erik Erikson, psychoanalysis has made "a family affair out of every historical event," but this was not Erikson's last word on the matter. He promptly would have intercepted critics inclined to rush his remark into their wholesale repudiations of the psychoanalytic approach. Erikson, after all, did more than any other psychohistorian to persuade us that domestic dramas do not end abruptly when sons and daughters leave home. ${ }^{31} \mathrm{He}$ and his admirers instructed historians to trade on domestic scenes when they are available, although it must be said that such scenes are not as available as many psychohistorians would have us believe. A stash of reminiscences readied for the composition of autobiography, for instance, frequently disguises or misrepresents the squalls of family life or the joys of childhood. To the extent that contempt or nostalgia has worked its "magic," the great treasure is untrustworthy, unless historians are concerned more with memory's tricks than with implicit trends. Memory's tricks are tantalizing bits of historical evidence, yet however scrupulously the adult author tries to remember and impersonate the child or the adolescent, crucial omissions or extrapolations queer the account.

Psychohistorians eager for family portraits sometimes overlook the likelihood of such inadvertent tampering and deliberate invention. And when family portraits are not available, some psychohistorians reach for the brush. Mary Maples Dunn, for one, can be caught doing too much with too little while she was hunting for "emotional determinants" that made William Penn's defiance of social authority intelligible and predictable. Dunn had evidence for Penn's nonconformity: his refusal to doff his hat at court ("hat behavior"), his conversion to the Quakers, his indiscriminant use of personal pronouns. Yet Penn was silent about his youth. The silence seems impenetrable, but friends of psychohistory allow that ordi-

31 Without reading Erikson's accounts of how Hans Luther purportedly haunted his son Martin's exegesis of the psalms and christology, one cannot fully appreciate the narrative power of psychohistory: Erik Erikson, Young Man Luther (New York, 1958), pp. 202-3, 210-13. But, for Erikson's comments on psychoanalysts' fetishes for the family, see his paper "On the Nature of Psycho-historical Evidence: In Search of Gandhi," in Psychoanalysis and History, ed. Bruce Mazlish (New York, 1971), p. 202. 
nary rules of evidence may have to be suspended in order to ship genuine insight into historical literature. Dunn had no direct evidence for Penn's youth. Assuming the child's presence in the adult, however, she speculated that her subject, in later life, was accumulating fresh ways to disobey his parents. In the final analysis, her paper on Penn bulldozed his idiosyncratic adult behavior into the empty pit of Penn's youth, and she trusted that "emotional determinants" would be formed by the backfill. ${ }^{32}$

Dunn's labors are important here because she was investigating the afterlife of filial defiance against odds greater than those we face when we confront the same issue with respect to Conrad Grebel's career. Her paper is also important as a relatively recent and representative specimen of the psychohistorian's craft, which perpetuates a practice that was popular even when biographers prospected for "subterranean hostility" in Woodrow Wilson's youth thirty years ago. ${ }^{33}$

Unlike pathographers, psychohistorians seem to have an irrepressible need to know what happens underground, in that secret parish aptly called by Joel Kovel "a realm of the repudiated and impossible," a place where the residue from experience and fantasy as well as unspoken hostilities get stored for subsequent use. ${ }^{34}$ Psychohistorians say that other investigators, who have no passion for negotiating a settlement between this underworld and the more familiar and visible lives of their subjects, have stopped short of complete comprehension. Ordinarily, historians are tempted to halt at a place marked "self-interest." Who needs "subterranean hostilities" and subliminal selves when naked self-interest seems to account for the course of human affairs? Psychohistorians reply that selfinterest, as such, is never really naked. Usually it has been cloaked with clever rationalizations, but even stripped of its sophistry, self-interest is a phenomenon that begs for further analysis. "The wishes that eventuate in self-interest may be instinctual or defensive in origin. They may stem from the erotic or aggressive drives in search of amorous targets or hap-

32 Mary Maples Dunn, "The Personality of William Penn," Proceedings of the American Philosophical Society 127 (1983): 316-21.

93 Alexander L. George and Juliette George, Woodrow Wilson and Colonel House: A Personality Study (New York, 1956), particularly pp. 3-13, 114, 289-91. In the same vein, see Cushing Strout, "William James and the Twice-Born Sick Soul," Daedalus 97 (1986): 1062-82. "Subterranean hostility" is also the concern of scholars responsible for psychohistorical expeditions to the sixteenth century. In addition to Erikson's treatment of Luther, see Nelson $H$. Minnich and W. W. Meissner, "The Character of Erasmus," American Historical Review 83 (1978): 588-624, for Erasmus's "denied, repressed, and unconscious resentment" (whereby his "abandoning father" and the debris from his broken home dictate the force of his later polemics against scholastics and fellow humanists); and Ulrich Bubenheimer, "Gelassenheit und Ablösung: Eine psychohistorische Studie über Andreas Bodenstein von Karlstadt und seinen Konflikt mit Martin Luther," Zeitschrift für Kirchengeschichte 92 (1981): 250-68, for Karlstadt's unacknowledged envy of his brother, a "deeper cause" of his contests with Luther.

94 Joel Kovel, The Age of Desire (New York, 1981), p. 71. 


\section{The Journal of Religion}

less victims, they may constitute an attempt to keep anxiety at bay." The chief objective of psychohistory is not to umpire the competition between theories and therapies. No single bookkeeper can order the unconscious completely to the satisfaction of theoretically informed colleagues. The psychohistorian's obligation is to "annex the unconscious and the incessant traffic between mind and world to the historian's legitimate territory of inquiry." 35

Pathography, however, is less concerned than psychohistory with questions of storage and recovery. One may concede that stated purposes and conscious aims do not always explain the conduct they are said to have prompted, yet one need not then streak after causes into the unconscious. Trends and patterns provide their own explanatory power, and they sometimes inspire pathography to perform some of its own breathtaking leaps from the adolescent to the adult.

In the case of Conrad Grebel, the interpretive leaps are easier to execute because the trends or patterns are relatively easy to identify. When Grebel thought he had been betrayed, he fell into despair and then staged his own mutinies. Heinold Fast was the only observor to have braided Grebel's intense personal feelings, his search for surrogate fathers, and his religious and political choices, but Fast drove pathography over the frontier of psychohistory by suggesting that there was something oedipal about Grebel's special curse. According to Fast, Grebel was compelled to surpass his father and father figures; to be more accurate, Fast allowed that psychoanal;́tic theory would make it seem so. Actually Fast doubted that the psychoanalytic approach had much merit. He offered it as an excusable yet by no means preferable reading of Grebel's behavior. He should be credited with having volunteered the explanation, yet his apprehension about its appropriateness possibly (and perversely?) provoked him to rely on some of psychohistory's more problematic concepts. Where Fast posits "fundamental psychological structures," it should be enough to suppose that bitter and unresolved domestic battles prohibited Grebel from reconciling his affection for authority figures with his need for autonomy ${ }^{36}$ Contemporary clinicians tell us that family conflict can lead either to mutual respect, which provides "vital ground for [a son's] self-definition," or to "pathological separation" and enduring enmity. Grebel and his father almost conscientiously held to the latter course, and we must not forget that Grebel denounced Zwingli soon after Zwingli decided to collaborate with the city councils' commission on worship and,

35 Peter Gay, Freud for Historians (New York, 1985), p. 209. Also see pp. 105-10 for "wishes that eventuate in self-interest."

36 Originally composed for Radikale Reformation, edited in 1978 by Hans-Jürgen Goertz, and published in Munich, Fast's "Conrad Grebel" is now available in Walter Klaassen's translation in Profiles of Radical Reformers (Scottdale, Pa., 1982), pp. 128-30 (pp. 112-14 in the original). 
during the commission's deliberations, with Grebel's father. ${ }^{37}$

At another point, Fast's half-hearted flirtation with some questionable psychoanalytic terminology suggests a second complaint. Fast proposed to ground Grebel's "theology of martyrdom" in Grebel's "death instinct," which, he admitted, was the most stupefying feature of his subject's character structure (am verblüffendsten). Here, as well, pathography should be able to trace the development of Grebel's discontent without installing instincts and structures.

We have seen already that Grebel was preoccupied with his suffering and death. Some of his earliest remarks on tribulation reflect his conviction that the good cause is always at a disadvantage in this world. He agreed, then, with his humanist friends who virtually cultivated anxieties about their friendship networks and their pessimisms about the fate of literature and learning. Erasmus claimed that he and his colleagues were besieged by barbarians and destined to suffer insults and injuries. Grebel learned that suffering was the route to righteousness and that melancholy was the mark of celebrity even before he "discovered" Scripture and realized that "Christ must suffer still more in his [more faithful] members."

The normative vision of Anabaptist origins construes Grebel's "theology of martyrdom" as a function of the radicals' distinctive exegesis. Contextualists see it as a reaction to the radicals' acquired outcast status, as if, in large part, the radicals simply made a virtue of necessity. Without minimizing the effects of exegesis or the importance of rejection and persecution, pathography, on this front, "sophisticates stereotypes," that is, pathography sets Grebel's developed thoughts on suffering and death in the stream of details from his previous perceptions and personal history. ${ }^{38}$ Ideally, we might then know why Grebel interpreted Scripture as he did and why he responded to pressure and to persecution as he did. Unlike much psychohistory, which certainly seems addicted to ontogenetic explanations of adult behavior, pathography stays north of the navel and west of the crib. Its goal is not to take the subject as an exhibit of universal instincts and psychic structures but to make the subject "empathically understandable."

Empathic understanding and pathography do not provide all the answers to questions raised by the emergence of Anabaptist separatism.

37 See L. David Levi, Helm Stierlin, and Robert J. Savard, "Fathers and Sons: The Interlocking Crises of Integrity and Identity," Psychiatry 35 (1972): 48-56. I imply here that contemporary clinical studies may be appropriated cautiously and without presuming that family environments monitored today resemble in every particular sixteenth-century family life.

38 The technique is similar to that of Richard E. Neustadt and Ernest R. May, Thinking in Time (New York, 1986), pp. 157-80. "Placing strangers," in their approach, blends "small |biographical] details" with "large historical events" in order to identify implicit trends and "to sophisticate stereotypes." 


\section{The Journal of Religion}

Causal explanations must be sufficiently complex and capacious to make room for ideas and exegesis as well as for anticlerical currents and socioeconomic contexts. But pathography should discipline some of the wilder speculations spawned by single-factor theories. Goeters's informative essay on Anabaptist prehistory, for example, assumes that Grebel would have fallen back in line behind Zwingli and Leo Jud had the government's commission on worship pressed for the elimination of the Catholic mass. But, if I am correct, that is quite unimaginable. Whatever the results of Zwingli's cooperation with the government, the fact that it also required Zwingli to work closely and companionably with Grebel's father tells against Goeters's guess. In 1523, if not before, Grebel's family feuds and filial defiance became influential parts of the Swiss reformations' history. ${ }^{39}$

39 Compare Goeters (n. 10 above), p. 279. 
Copyright of Journal of Religion is the property of University of Chicago Press and its content may not be copied or emailed to multiple sites or posted to a listserv without the copyright holder's express written permission. However, users may print, download, or email articles for individual use. 